Primljen / Received: 5.1.2016. Ispravljen / Corrected: 27.8.2016.

Prihvaćen / Accepted: 1.9.2016. Dostupno online / Available online: 10.8.2017.

\section{Effect of sleeve length on deformation properties of grouted splices}

Authors:

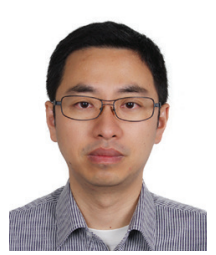

Assoc.Prof. Feng Lin, PhD. CE

Tongji University

Department of Structural Engineering

Shanghai, China

lin_feng@tongji.edu.cn

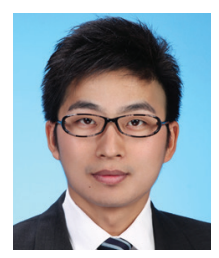

Xiaobao Wu, MSc. CE

Tongji University

Department of Structural Engineering

Shanghai, China

xiaobaowu@126.com
Scientific paper - Preliminary report

Feng Lin, Xiaobao Wu

\section{Effect of sleeve length on deformation properties of grouted splices}

Tests on 12 grouted splices were performed to investigate their deformation properties under tensile loading. Test variables included diameter and type of spliced bars and the size of splicing sleeves. Finite element method based models of the splices were built, verified and used to investigate the effect of sleeve length on the deformation properties of the grouted splices. The sleeve length significantly affected the failure modes and further affected the splices' deformation properties. A recommendation was proposed to maximize deformation properties of a specific splice by using a critical sleeve length associated with failure mode of bar fracture.

Key words:

grouted splice, sleeve connector, experimental study, numerical simulation, deformation performance

Prethodno priopćenje

Feng Lin, Xiaobao Wu

Utjecaj dužine cjevastog spoja na deformacijska svojstva injektiranih spojeva

Provedeno je ispitivanje dvanaest injektiranih spojeva armaturnih šipki da bi se utvrdila njihova deformacijska svojstva pod vlačnim opterećenjem. Promjenjivi parametri tijekom ispitivanja bili su promjer i vrsta spojnih šipaka te veličina cjevastih spojeva. Izrađeni su, provjereni i korišteni odgovarajući modeli bazirani na metodi konačnih elemenata kako bi se odredio utjecaj dužine spoja na deformacijska svojstva injektiranih spojeva. Dužina spoja znatno je utjecala na način sloma i na deformacijska svojstva spojeva. Predložena je metoda poboljšanja deformacijskih svojstava određene vrste spoja primjenom kritične dužine spoja i načina loma šipke.

Ključne riječi:

injektirani spoj, cjevasti spoj, eksperimentalno istraživanje, numerička simulacija, deformacijska svojstva

Vorherige Mitteilung

Feng Lin, Xiaobao Wu

Einfluss der Länge der röhrenförmigen Verbindung auf die Verformungseigenschaften der injizierten Verbindungen

Durchgeführt wurde eine Untersuchung von zwölf injizierten Verbindungen von Bewehrungsstäben, um deren Verformungseigenschaften unter Zuglast festzustellen. Es wurden entsprechende Modelle angefertigt, überprüft und genutzt, die sich auf der Methode der endgültigen Elemente basieren, um den Einfluss der Länge der Verbindungen auf die Verformungseigenschaften der injizierten Verbindungen festzulegen. Die Länge der Verbindung hatte wesentlichen Einfluss auf die Art des Bruchs und die Verformungseigenschaften der Verbindungen. Empfohlen wurde eine Methode für die Verbesserung der Verformungseigenschaften einer bestimmten Verbindungsart durch Anwendung einer kritischen Verbindungslänge und Bruchart des Stabes.

Schlüsselwörter:

injizierte Verbindung, röhrenförmige Verbindung, experimentelle Untersuchung, nummerische Simulation 


\section{Introduction}

Grouted splices are commonly used in concrete to connect discontinuous reinforcing steel bars, particularly in precast concrete components. Figure 1 illustrates a grouted splice (to be referred to as splice from this point forward) of typical configuration. Two separated bars were embedded in the grout and confined by a coupling sleeve. During construction, the projected bars from one precast component were inserted into the sleeve prefabricated in another precast component. Then, high-strength and nonshrink cementations grout was introduced into the sleeve and around the bars using a low-pressure grout pump. In addition, ribs were produced on the interior surface of the sleeves to increase resistance of the grout-sleeve bond. A stop was placed in the sleeve's midsection to ensure appropriate positioning of the two bars. By doing this, the lateral confinement could be produced in a small region along the bars, which ensured a transfer of axial force from one bar to another. This type of splice provides structural integrity and is economical and easy to operate compared to other splice methods, e.g., lap splices welded splices and mechanical connections.

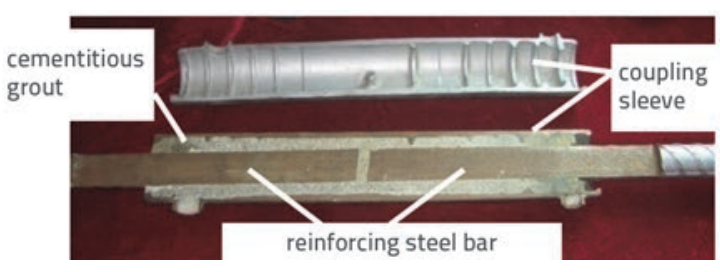

grout-sleeve bond

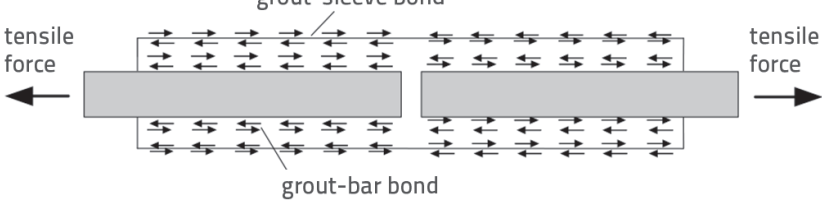

Figure 1. Grouted splice of a typical configuration

A variety of splices were proposed with their coupling sleeves of various geometrical and mechanical configurations. Experiments have been conducted to understand the mechanical performance of the splices. Einea et al. [1] studied the applicability of simple and inexpensive grouted splices fabricated from standard steel pipes. Specimens with different parameters and geometrical design were tested under tension. For the purpose of evaluating their suitability in connecting precast concrete structural elements, Jansson [2] tested two proprietary splices in the aspects of slip, fatigue, ultimate load and creep. Recently, Ling et al. [3,4] and Hosseini and Rahman [5] proposed a series of splices varied in terms of configurations, most of them fabricated from standard-sized steel pipes, and experimentally investigated their mechanical performance. To avoid the tight tolerances when using current production, Henin and Morcous [6] proposed a non-proprietary splice which is capable of fully developing the ultimate strength of the spliced bars. Based on these previous studies, a fundamental understanding of the mechanical performance of splices was set forth as follows:

- Splices with their sleeves of various configurations resulted in mechanical behaviour significantly differing from each other [1-6].

- For splices that reacted appropriately in tests and met the acceptance criteria in, e.g., ACl-318 [7], AC-133 [8] and BS8110-1 [9], two failure modes of bar fracture and groutbar bond failure were observed [2].

- Generally, the ultimate tensile stress of the spliced bars was slightly less than the ultimate strength of the used bars. The reason for this difference in strength was believed to be caused by the misalignment and offset of the embedded bars $[2,4]$. The misalignment and offset generated secondary moments, which led to non uniform stress distribution in the critical section of the bars. This caused local and earlier failure compared to cases based on purely axial loading. As a result, the ultimate strengths and ultimate strains of the splices decreased.

- Deformation properties of the splices were thought to be not as strong as the used bars, because of the relatively weak deformation capacity of the sleeve segment [10]. Unfortunately, related data were scarce.

As a result, the deformation properties of the splices and their influencing factors were not well understood compared to that of their ultimate strengths. In fact, the deformation properties significantly affect the mechanical performance of structural components, especially when splices are used in plastic hinge areas [11]. Consequently, it was not fully confident to understand the behaviour of structural components using the splices.

The main objective of this paper was to investigate deformation properties of the splices and their influencing factors. This was done by means of experimental studies and a numerical model based on the finite element method (FEM). A recommendation was then presented that could be applied in the design process of products to improve their deformation properties.

\section{Experimental programme}

\subsection{Materials and specimen fabrication}

The splices used in this study consisted of three components, i.e., four sizes of coupling sleeve (5VSA, 7VSA, 8VSA and 1OVSA), grout, and two grades of reinforcing steel bars (HRB400 and HRB500). The coupling sleeves and grout were manufactured by a producer and are commercially available. Figure 2 illustrates the details of the coupling sleeves. Four sizes of the sleeves, each with a specific configuration and 


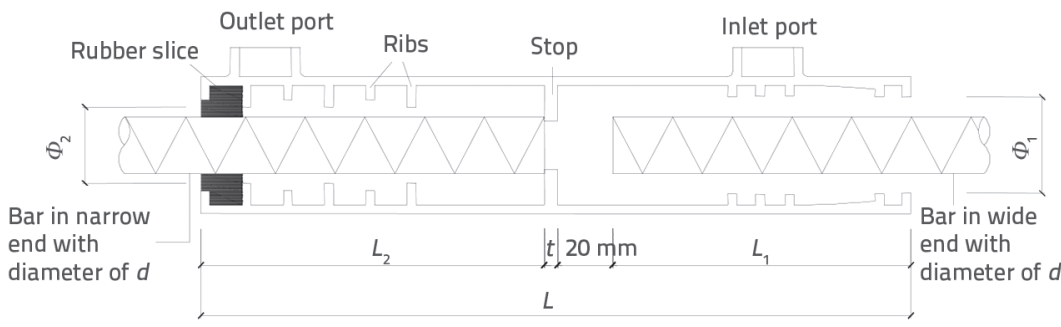

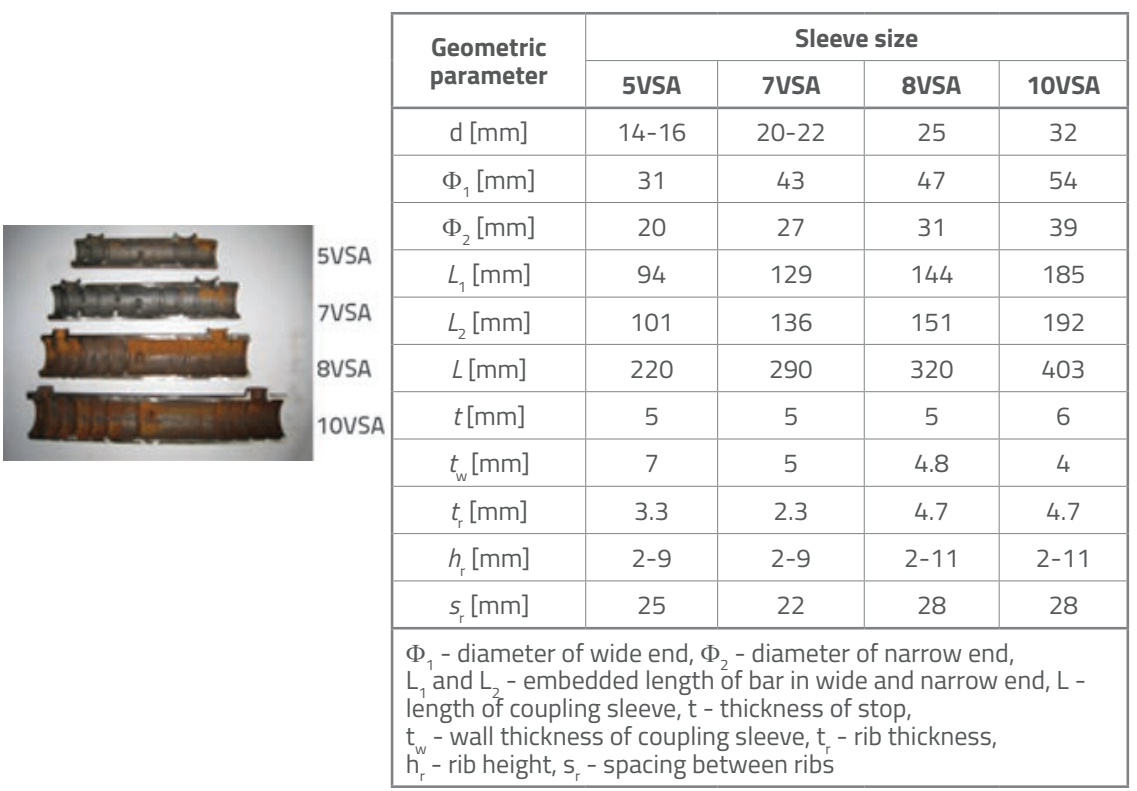

Figure 2. Coupling sleeves used in this study

Table 1. Material properties of grout

\begin{tabular}{|c|c|c|c|c|}
\hline $\begin{array}{c}\text { Axial compressive } \\
\text { strength }{ }^{*} f_{\mathrm{gg}}[\mathrm{MPa}]\end{array}$ & $\begin{array}{c}\text { Elasticity modulus } E_{\mathrm{g}} \\
{\left[\times 10^{4} \mathrm{MPa}\right]}\end{array}$ & $\begin{array}{c}\text { Tensile strength } f_{\mathrm{tg}} \\
{[\mathrm{MPa}]}\end{array}$ & $\begin{array}{c}\text { Ultimate } \\
\text { strain }\end{array}$ & $\begin{array}{c}\text { Fluidity } \\
{[\mathrm{mm}]}\end{array}$ \\
\hline 84 & 2.9 & 3.5 & 0.0035 & $180-270$ \\
\hline * prism $70.7 \times 70.7 \times 230 \mathrm{~mm}$ & & & & \\
\hline
\end{tabular}

Table 2. Material properties of reinforcing steel bars

\begin{tabular}{|c|c|c|c|c|c|c|c|}
\hline Grade & $\begin{array}{c}\text { Diameter } \\
\boldsymbol{d}[\mathrm{mm}]\end{array}$ & $\begin{array}{c}\text { Yield } \\
\text { strength } \\
f_{\mathrm{ys}}[\mathrm{MPa}]\end{array}$ & $\begin{array}{l}\text { Ultimate } \\
\text { strength } \\
f_{\mathrm{us}}[\mathrm{MPa}]\end{array}$ & $\begin{array}{l}\text { Elasticity modulus } \\
\qquad E_{\mathrm{s}}\left[\times 10^{5} \mathrm{MPa}\right]\end{array}$ & $\begin{array}{c}\text { Ultimate } \\
\text { strain } \\
\varepsilon_{\text {us }}\end{array}$ & $\begin{array}{l}\text { Yield platform length } \\
\qquad \Delta \varepsilon_{\mathrm{ys}}\end{array}$ & $\begin{array}{c}\beta_{\mathrm{m}} \\
\left(f_{\mathrm{us}} / f_{\mathrm{ys}}\right)\end{array}$ \\
\hline \multirow{6}{*}{ HRB400 } & 14 & 532 & 656 & 1.89 & 0.12 & 0.022 & 1.23 \\
\hline & 16 & 551 & 685 & 1.97 & 0.11 & 0.017 & 1.24 \\
\hline & 20 & 427 & 569 & 1.79 & 0.15 & 0.016 & 1.33 \\
\hline & 22 & 503 & 675 & 2.15 & 0.13 & 0.016 & 1.34 \\
\hline & 25 & 519 & 657 & 2.13 & 0.12 & 0.019 & 1.27 \\
\hline & 32 & 424 & 586 & 1.84 & 0.12 & 0.012 & 1.38 \\
\hline \multirow{6}{*}{ HRB500 } & 14 & 605 & 741 & 2.11 & 0.12 & 0.017 & 1.22 \\
\hline & 16 & 615 & 768 & 1.82 & 0.12 & 0.015 & 1.25 \\
\hline & 20 & 619 & 765 & 2.18 & 0.11 & 0.012 & 1.24 \\
\hline & 22 & 597 & 755 & 1.90 & 0.11 & 0.015 & 1.27 \\
\hline & 25 & 571 & 733 & 2.00 & 0.12 & 0.015 & 1.28 \\
\hline & 32 & 555 & 719 & 1.85 & 0.12 & 0.017 & 1.30 \\
\hline
\end{tabular}

geometric parameters, were used for different diameters of connected bars. The sleeves were cast of ductile iron. Their mechanical properties were provided by the manufacturer and in accordance with the Chinese code [10]. The ultimate strength and ultimate strain of the ductile iron were no less than $600 \mathrm{MPa}$ and $3 \%$, respectively. The spheroidization rate of the ductile iron was no less than $85 \%$ and the Brinell hardness ranged from 180 to $250 \mathrm{HBW}$. Tables 1 and 2 present the material properties of the grout and reinforcing steel bars on the $28^{\text {th }}$ day of testing. All data in the tables represent three specimens and their mean values after testing. The strengths of the bar grade HRB500 were relatively high compared to those of HRB400. In fabrication of the splices, the sleeves were first placed vertically by means of timber fixture, as illustrated in Figure 3. The bars were then carefully inserted into the sleeves from its two ends to make the two bars line up as accurately as possible. A ring-form rubber seal was used at the narrow end of each coupling sleeve 
to prevent grout leakage. Afterwards, the grout was poured in the sleeves from inlet ports using a grout pump. Finally, the splice specimens were removed from the fixture after 24 hours and horizontally placed at room temperature for about 28 days until the testing.

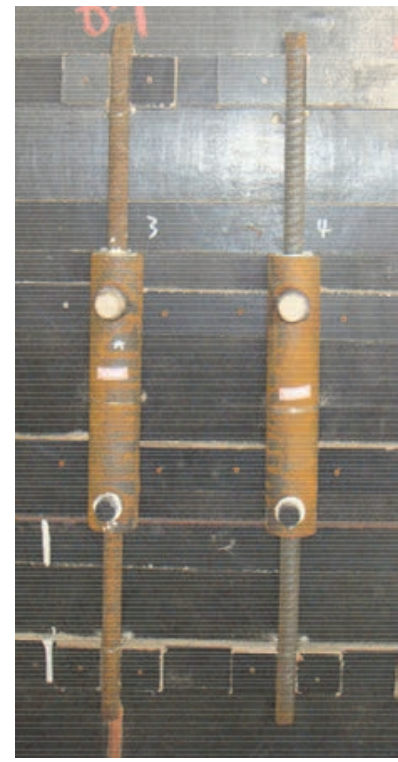

Figure 3. Grouted splice specimens

\subsection{Test setup}

Table 3 presents the details of 12 specimens under tensile loadings, including two grades of bars with each of six diameters. A $500 \mathrm{kN}$ servo-hydraulic actuator with an accuracy of $2 \mathrm{kN}$ was used for loading until specimen failure. Figure 4 illustrates the test setup and arrangement of the displacement transducers and strain gauges. The measured data included loading forces, sleeve strains, and splice deformations within gauge length of $L_{4}\left(L_{4}\right.$ $=L+8 d$, where $L$ and $d$ denote sleeve length and bar diameter, respectively).The loading force was controlled with a stress rate of about $30 \mathrm{MPa} / \mathrm{s}$ before bar yielding and beyond that was transferred to displacement control with a strain rate of about $0.002 / \mathrm{s}$. The loading forces were recorded automatically by a data acquisition device of the actuator. Strain distribution of each coupling sleeve was investigated by sticking strain gauges, $s p_{1}$ to $s p_{6^{\prime}}$ along the length direction on its external surface. Two displacement transducers with an accuracy of $0.01 \mathrm{~mm}$ were used for each specimen and their average values were applied to obtain deformations. For each specimen, the relative elongation $\delta$ could be calculated by means of the elongation $u$ and deformation at ultimate load $L_{T}$ by using equation (1) expressed as:

$\delta=\frac{\mathrm{u}}{\mathrm{L}_{4}}$ gdje je $\mathrm{u}=\mathrm{L}_{\mathrm{T}}-\mathrm{L}_{4}$
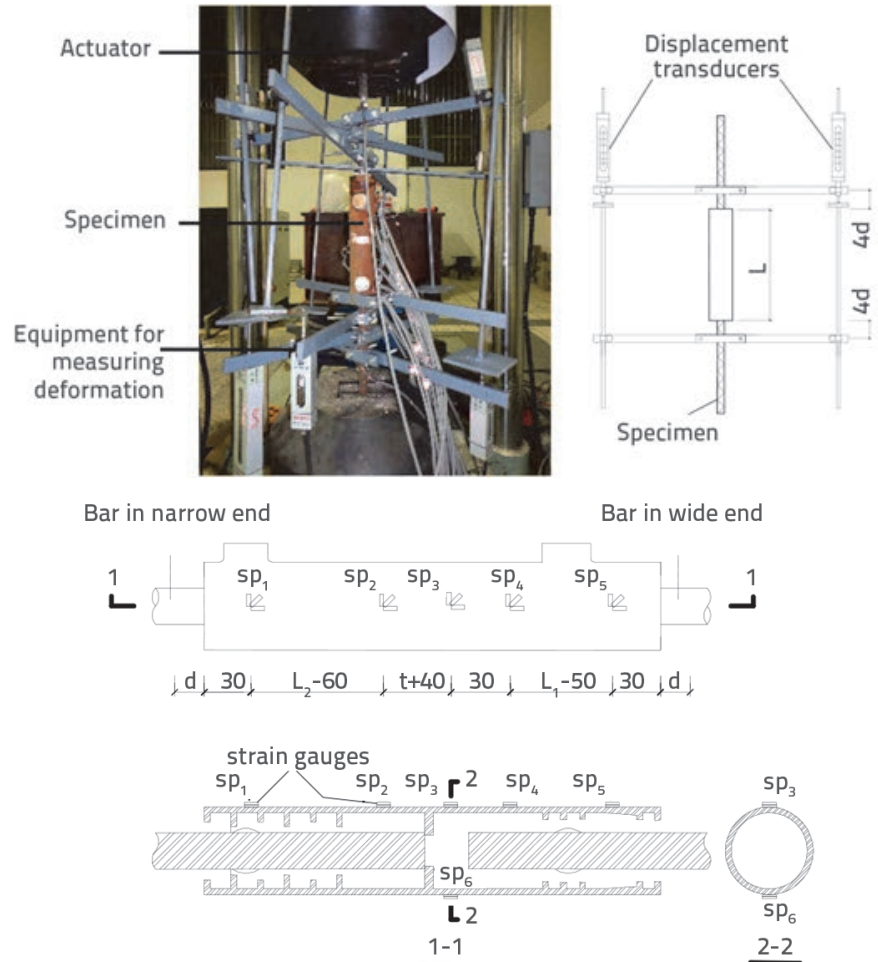

Figure 4. Test setup and arrangementsof displacement transducers and strain gauges

Table 3. Specimen details

\begin{tabular}{|c|c|c|c|}
\hline $\begin{array}{l}\text { Specimen } \\
\text { grade }\end{array}$ & $\begin{array}{l}\text { Bar } \\
\text { grade }\end{array}$ & $\begin{array}{c}\text { Bar diameter } \\
{[\mathrm{mm}]}\end{array}$ & $\begin{array}{l}\text { Sleeve } \\
\text { size }\end{array}$ \\
\hline H400D14 & \multirow{6}{*}{ HRB400 } & 14 & 5VSA \\
\hline H400D16 & & 16 & 5VSA \\
\hline H4OOD20 & & 20 & 7VSA \\
\hline H400D22 & & 22 & 7VSA \\
\hline H400D25 & & 25 & 8VSA \\
\hline H400D32 & & 32 & 10VSA \\
\hline H500D14 & \multirow{6}{*}{ HRB500 } & 14 & 5VSA \\
\hline H500D16 & & 16 & 5VSA \\
\hline H500D20 & & 20 & 7VSA \\
\hline H500D22 & & 22 & 7VSA \\
\hline H500D25 & & 25 & 8VSA \\
\hline H500D32 & & 32 & 10VSA \\
\hline
\end{tabular}

\section{Test results and discussion}

\subsection{Test results}

Table 4 summarizes the test results in terms of failure modes, ultimate loads, deformations, and relative elongations. 
Table 4. Tests results

\begin{tabular}{|c|c|c|c|c|c|c|}
\hline $\begin{array}{l}\text { Specimen } \\
\text { grade }\end{array}$ & $\begin{array}{l}\text { Ultimate load } \\
\qquad \boldsymbol{P}_{\mathrm{u}}[\mathrm{kN}]\end{array}$ & $\sigma_{u}^{*} / f_{u s}$ & $\begin{array}{l}\text { Elongation } \\
\quad u[\mathrm{~mm}]\end{array}$ & $\begin{array}{c}\text { Relative elongation } \\
\delta[\%]\end{array}$ & $\delta / \varepsilon_{\mathrm{us}}$ & Failure mode \\
\hline H400D14 & 88 & 0.87 & 20.3 & 6.1 & 0.53 & Bar fracture \\
\hline H400D16 & 126 & 0.91 & 20.8 & 6.0 & 0.56 & Bar fracture \\
\hline H400D20 & 187 & 1.04 & 38.5 & 8.6 & 0.55 & Grout-bar bond failure \\
\hline $\mathrm{H} 400 \mathrm{D} 22$ & 229 & 0.89 & 16.9 & 3.6 & 0.29 & Grout-bar bond failure \\
\hline H40OD25 & 303 & 0.94 & 22.9 & 5.8 & 0.47 & Grout-bar bond failure \\
\hline H400D32 & 463 & 0.98 & 29.8 & 4.5 & 0.39 & Grout-bar bond failure \\
\hline H500D14 & 104 & 0.91 & 18.4 & 5.5 & 0.46 & Bar fracture \\
\hline H500D16 & 136 & 0.88 & 13.7 & 3.9 & 0.33 & Grout-bar bond failure \\
\hline H500D20 & 222 & 0.92 & 27.3 & 6.1 & 0.57 & Grout-bar bond failure \\
\hline $\mathrm{H} 500 \mathrm{D} 22$ & 249 & 0.87 & 16.3 & 3.5 & 0.31 & Grout-bar bond failure \\
\hline H500D25 & 320 & 0.89 & 16.6 & 3.2 & 0.27 & Grout-bar bond failure \\
\hline H500D32 & 549 & 0.90 & 20.1 & 3.0 & 0.26 & Grout-bar bond failure \\
\hline \multicolumn{2}{|c|}{$\begin{array}{c}\text { Mean value } \\
\text { (coefficient of variation) }\end{array}$} & $\begin{array}{c}0.92 \\
(0.055)\end{array}$ & - & - & $\begin{array}{c}0.42 \\
(0.29)\end{array}$ & - \\
\hline
\end{tabular}

Figure 5 illustrates two failure modes observed in tests, i.e., bar fracture and grout-bar bond failure resulting in bar pull-out. The two failure modes were also observed in previous studies $[1,2,4]$ for well-designed products. Sleeve tensile failure and grout-sleeve bond failure as found in $[1,2,4]$, did not occur in this study. This was probably because the resistance forces provided by the coupling sleeve and grout-sleeve bond were relatively strong compared to those provided by the bars and grout-bar bond in this study.

The stresses of bars at ultimate loads averaged $92 \%$ of the ultimate tensile strength of the connected bars. The main reasons, as mentioned in Section 1, were believed to be due to the misalignment and offset of the embedded bars for bar fracture $[2,4]$. For grout-bar bond failure, the relatively weak resistance force provided by the grout-bar bond also played a role.

The relative elongations $\delta$ presented in Table 4 ranged from 3.0\% to $8.6 \%$. The ratios of the relative elongations of the splices, $\delta$, to the ultimate strains of the bars, $\varepsilon_{\text {us' }}$ varied from 0.26 to 0.57 with an average of 0.42 . This meant the deformation capacities of the splices were significantly weaker compared to those of the bars. Evidently, this result also revealed that relatively weak deformation properties of the splices can be attributed to the sleeve segment [10]. Note that the exact values of $\delta$ and $\delta /$ $\varepsilon_{\text {us }}$ varied with the chosen gauge length, but the conclusions concerning the weak part of the splices were independent of the chosen gauge length.

Figure 6 presents typical load-deformation responses of specimens H400D14 and H500D14 with failure mode of bar fracture, and those of specimens H400D22 and H500D22 with grout-bar bond failure mode. Four horizontal lines in the figure from the bottom up denote yield loads of bars HRB400 and HRB500 as well as ultimate loads of bars HRB400 and HRB500, respectively. Three stages can be recognized from the curves, i.e., elastic, yield and hardening stages. Note that the characteristic of three stages in the curves applied to both failure modes, because all connected bars were in the post-yielding state when the specimens failed.

Figure 7 illustrates the representative peak values of the strain distribution of coupling sleeves for specimens H400D22 and H5OOD22. The values on the horizontal axis indicate the distances from the narrow end of the sleeve to the measured points. Results found that in the longitudinal direction, coupling sleeves were in tension. The peak value of each specimen appeared in the midsection and decreased gradually towards the two sleeve ends .In the transverse direction, the strains were relatively small and the sleeves were in tension or compression. An explanation for these observations can be found in [3].

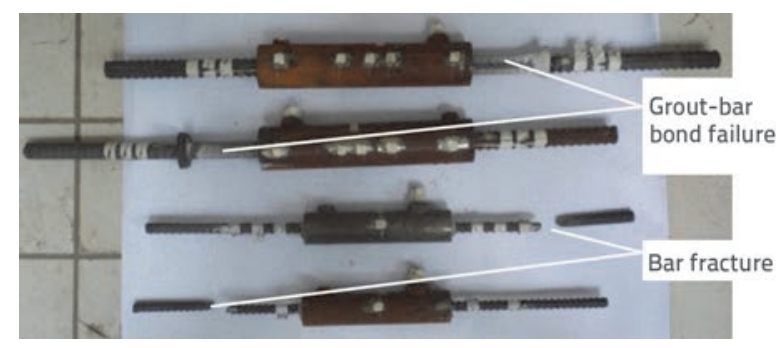

Figure 5. Two observed failure modes 


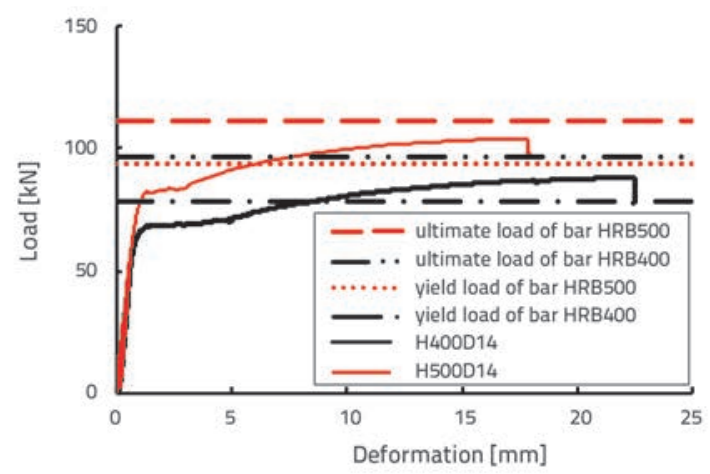

Figure 6. Typical load-deformation curves

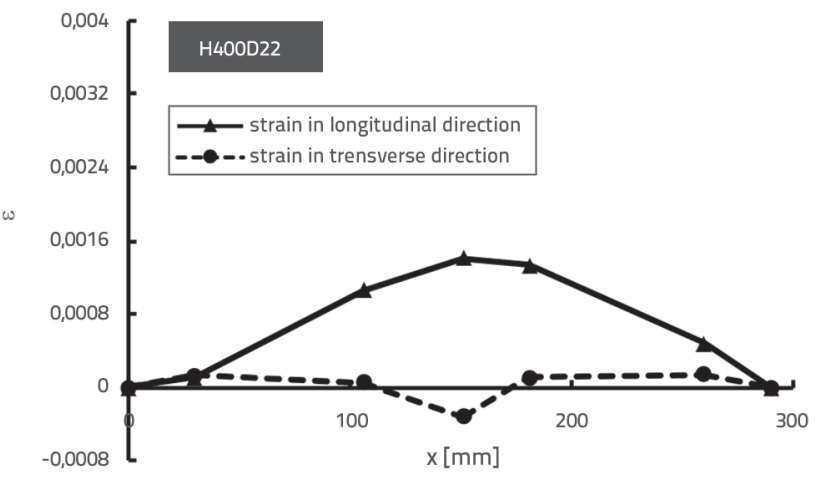

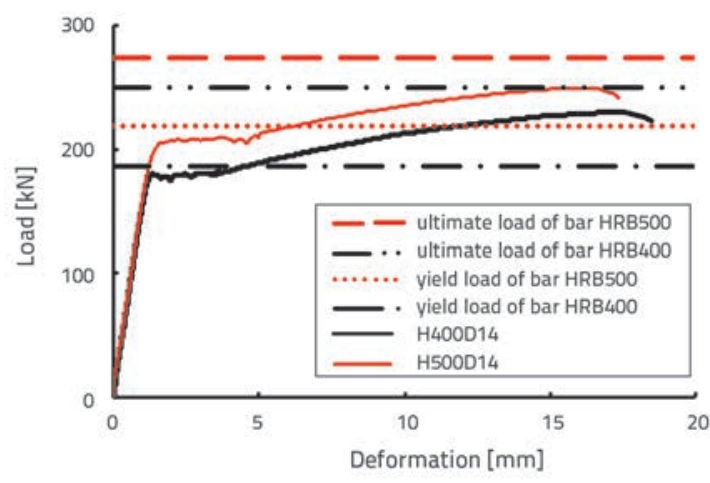

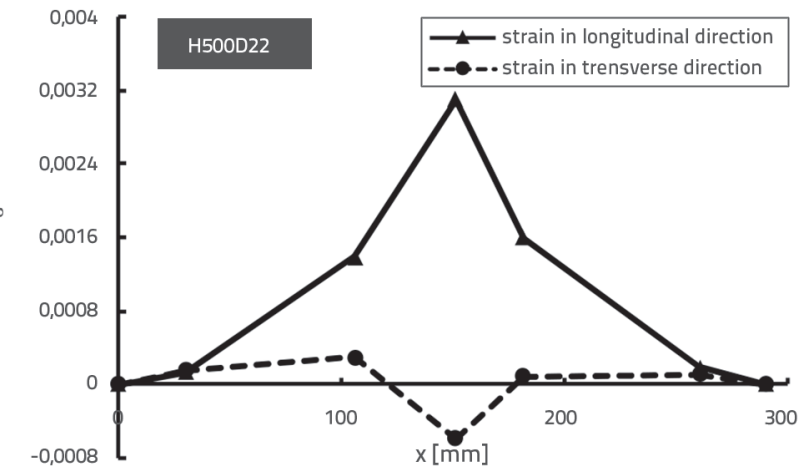

Figure 7. Peak strain distribution on the external surface of the coupling sleeves of specimens H400D22 and H500D22

\subsection{Discussion}

Test results revealed that failure mode affected the deformation properties of the splices. For the bar fracture with almost full use of the bars, i.e., in the cases of specimens H400D14, H400D16, and H500D14 in Table 4, the mean value of $\delta / \varepsilon_{\text {us }}$ was 0.52 . However, for the grout-bar bond failure where the bars did not develop to their ultimate strains, the values of $\delta / \varepsilon_{\text {us }}$ averaged 0.38 . These results were consistent with the understanding that the deformation capacities of bars were better than those of the sleeve segments [10]. As a result, the splices that failed in bar fracture tended to improve their deformation capacities.

Moreover, the failure modes were significantly affected by sleeve lengths, when other factors were determined in advance, e.g., configurations of sleeve's interior surface and material of sleeve. In this condition, for a specific splice, a minimum length of the sleeve existed to ensure bar fracture and maximized its deformation properties. In other words, splices with longer sleeve lengths than the minimum one also led to bar fracture; however, they also caused length reduction of the bars located outside and, therefore, resulted in degeneration of overall deformation properties. This understanding will be further numerically verified in Section 4.

Finally, all the specimens were tested in air without surrounding concrete, which is different from the actual service condition of the splices imbedded in concrete in reinforced concrete elements. The authors believe that the restraining function of the surrounding concrete would reduce the undesired effects of the misalignment and offset of connected bars on the mechanical properties of the splices. As a result, the splices with surrounding concrete tended to act in a purely axial condition and the tested results presented in this paper could be considered as having a safe margin.

\section{Numerical studies}

The purpose of this section was to investigate the effect of sleeve length on the deformation properties and to present an approach to maximize the deformation properties of the splices. Commercially available software ANSYS was used to build the FEM model.

\subsection{FEM model}

The eight-node solid element, Solid 65, commonly used for concrete, was chosen for the grout because of its capability to model the nonlinear behaviour of materials including cracking in tension and crushing in compression. The eight-node solid element, Solid 45, and beam element, Beam 188, were applied to the coupling sleeves and bars, respectively. The grout-bar bond action in the longitudinal direction and transverse constraint provided by the grout to bars in the radial direction were both using nonlinear spring 
element Combin 39. Along the longitudinal direction of the sleeves, the forcedisplacement relationship of the springs was determined based on the model proposed in [12], because the material and test features there were similar to those in this study. In the radial direction, springs were set with their high stiffness a)

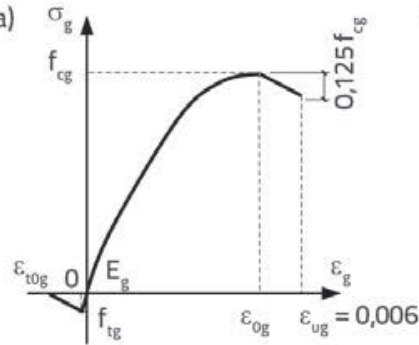

b)

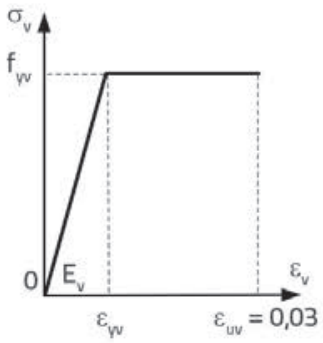

c)

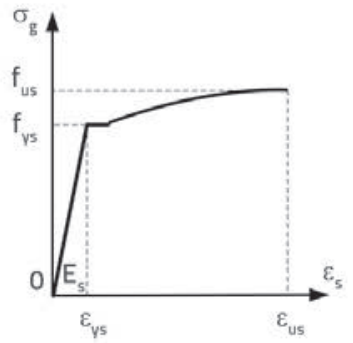

Figure 8. Stress-strain curves for materials under uniaxial loadings: a) grout; b) coupling sleeve; c) reinforcing steel bar

was fixed and the axial loading was applied at the wide end. A static implicit algorithm and arc-length method were used. The established FEM model is presented in Figure 9. coupling sleeves because grout-sleeve bond failure did not occur in the tests and their relative slip was considered to be minor. The ribs on the interior surfaces of the sleeves were also geometrically modelled. The length of the reinforcing steel bars outside the coupling sleeves was $4 d$ at each end of the specimens and in accordance with the tests.

The material behaviour of the grout, coupling sleeve and bar was described using multi-linear kinematic hardening models. Figure 8a delineates the stress-strain curve for the grout under axial loading primarily according to test results. Its failure behaviour was described using the William-Warnke failure criterion with five parameters. The shear transfer coefficients for open and closed cracks in the grout were adopted as the commonly used values of 0.4 and 0.95 , respectively. An ideally elastic-plastic material model presented in Figure 8b was used for the coupling sleeves with an assumed yield strength of $600 \mathrm{MPa}$ and an elasticity modulus of $2.1 \times 10^{5} \mathrm{MPa}$ [10]. The stress-strain curve for the reinforcing steel bars is shown in Figure $8 \mathrm{c}$ with the parameters in accordance with test results.

One difficulty in the model was to reasonably consider the misalignment and offset of the connected bars, which significantly affect the mechanical behaviour of the splices and were difficult to accurately measure. In this study it was assumed that the effect of the misalignment and offset could be appropriately described by using a loading eccentricity $e_{\text {, }}$ which also led to degradation of strength and deformation. A certain value of loading eccentricity was determined by trial computations and was applied to all specimens. Following this idea: First, specimen H500D14 was chosen as a representative splice because the value, $\sigma_{\mathrm{u}} / f_{\text {us' }}$ was 0.91 , which was close to the mean value of 0.92 (see Table 4). Second, loading eccentricities of specimen H500D14 increased from 0 to obtain the simulated ultimate load of the bars. Third, it was found that the simulated ultimate load was almost equal to the tested one when $e=0.035 d$. Finally, $0.035 d$ was set as the uniform loading eccentricity for all specimens in an approximate and simplified manner. During the computations, the narrow end of each coupling sleeve

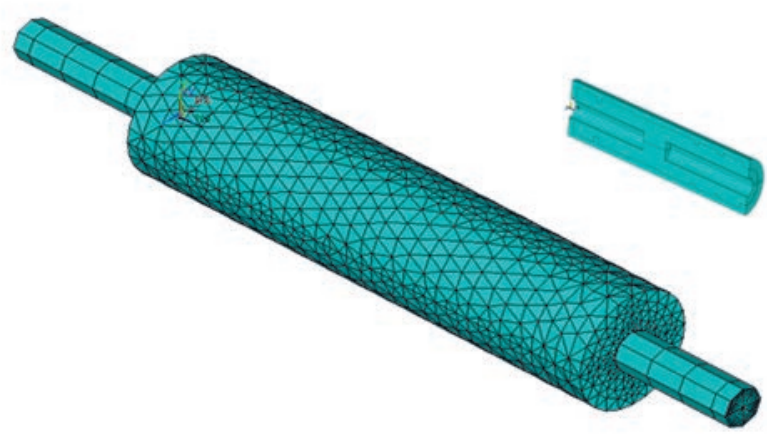

Figure 9. FEM model for grouted splices

\subsection{Model verification}

The model was verified by comparing the simulated results with the tested ones in terms of failure mode, ultimate load, load-deformation curve and strain distribution of the sleeves.

The simulated failure modes of all specimens were consistent with tested ones except for specimen H400D16 with grout-bar bond failure.

Figure 10a compares the simulated ultimate loads with the tested ones. The ratios of simulated-to-tested ultimate loads ranged from 0.92 to 1.04 , with a mean value of 1.00 and a coefficient of variation of 0.035 .

Figure 10b illustrates a typical load-deformation curve of specimen H400D22, showing that the simulated curve was close to the tested one.

Figure 10c presents the simulated and tested peak strain distribution on the external surface of the coupling sleeve of specimen H400D22. Both strains in the longitudinal and transverse directions were appropriately predicted. The variances probably occurred because the bar ribs and grout cracking were not realistically simulated in the model.

As a result, the developed FEM model was well verified and could be used for an application study. 
a)

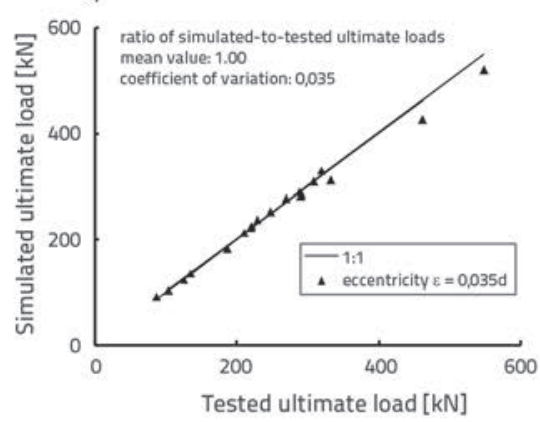

b)

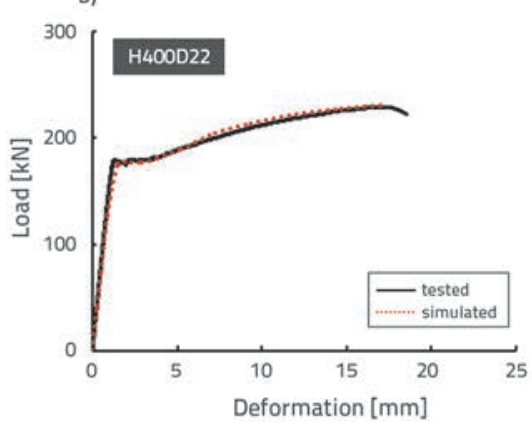

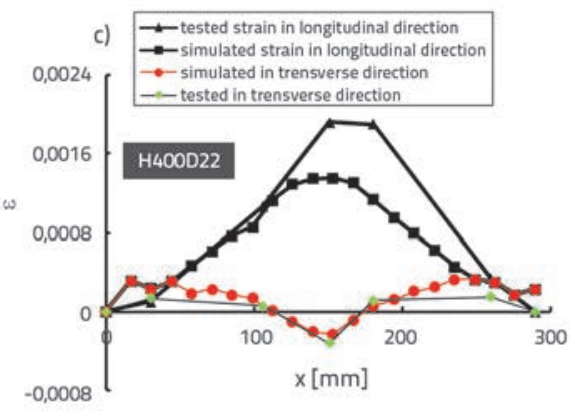

Figure 10. Comparison of the simulatedresults with tested ones: a) ultimate loads, b) load-deformation curve, c) peak strain distribution on the external surface of coupling sleeve

\subsection{Application}

The FEM model was used to study the effect of sleeve length on the deformation properties of splices. Note that:

- deformation capacities of the sleeve segments were relatively weak compared to the connected bars, which was verified in Section 3

- the bars were assumed to be in a post-yielding state at ultimate loads, which was true for all specimens in the tests.

Take specimen H400D14 as an example. Table 5 presents the effect of sleeve length on relative elongation, ultimate strength and failure mode. The sleeve length was decreased with an increment of $\Delta l$, ranged from $-2.0 d$ to 0 with an increment of $0.5 d$. As a result, the length of each bar embedded in the sleeve varied $\Delta / / 2$. It was found the relative elongation, $\delta$, reached its peak value when the failure mode transferred from grout-bar bond failure to bar fracture. For a specific splice, the sleeve length, which corresponded to the maximum relative elongation, was defined as a critical sleeve length $L_{c r^{\prime}}$ Alternatively, a critical sleeve length meant a minimum sleeve length associated with failure mode of bar fracture.

The concept of critical sleeve length can also be understood from the viewpoint of material usage. Before reaching $L_{c r}$ $\delta$ and $\sigma_{u}$ increased with the increase of sleeve length $L$. In these cases, the bars stresses fell in Region 1 illustrated in Figure 11, which means the bars were not made full use of at specimen failure. After exceeding $L_{\mathrm{c}^{\prime}} \delta$ decreased and $\sigma_{u}$ remained almost constant. Consequently, the bar stresses went into Region 2 in Figure 11, and the bars were used almost to their ultimate capability, resulting in an improvement of the deformation properties of the splices.

In this sense, an optimization design of the splices was performed in terms of investigating their critical lengths, as presented in Table 6 . It was found that the relative elongations improved $33 \%$ on average using critical sleeve lengths compared to the numerical results without optimization. Meanwhile, the bar stresses at ultimate loads only slightly increased and can be ignored. In addition, for specimen
H400D16, $L_{c r}=228 \mathrm{~mm}$, was slightly greater than $L=220$ $\mathrm{mm}$, with an error of about 3.6\%.For specimen H400D20, an unexpected small $L_{c r}$ was obtained, which can probably be attributed to the variation in material tests. Finally, the understanding of critical sleeve length was accepted as having a general meaning because it is independent of the loading eccentricities and gauge lengths.

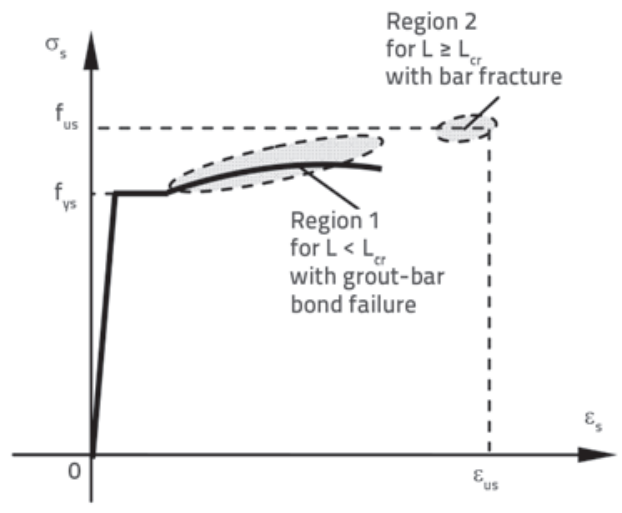

Figure 11. Bar stress in case of different failure modes of splices

\subsection{Recommendation for design of the splices}

Current methods of product design for splices have deficiencies with respect to deformation properties. Various splice products have been designed with their mechanical performance set to meet the acceptance criteria [7-10]. Most of these criteria are generally related to strength issues and do not include deformation properties. However, as is well known, deformation properties of the splices are essential for sound structural behaviour, e.g., appropriate energy-absorbing capability. Therefore, current acceptance criteria cannot be relied upon with total confidence when they are used to evaluate splices applied in plastic hinge zones [12] or in structures built in earthquake-prone areas. In this regard, methods concerning improving deformation properties of splices are meaningful.

One recommendation for product design was proposed based on this study, i.e., critical sleeve lengths should be 
Table 5. Effect of sleeve length on relative elongation and ultimate strength of specimen H400D14

\begin{tabular}{|c|c|c|c|c|c|}
\hline $\begin{array}{c}\text { Sleeve length } \\
L[\mathrm{~mm}]\end{array}$ & $\Delta I[\mathrm{~mm}]$ & $\begin{array}{l}\text { Gauge length } \\
L_{4}=L+8 d[\mathrm{~mm}]\end{array}$ & $\begin{array}{c}\text { Relative elongation } \\
\delta[\%]\end{array}$ & $\begin{array}{c}\sigma_{u} \\
{[\mathrm{MPa}]}\end{array}$ & Failure mode \\
\hline 192 & $-2.0 d$ & 304 & 2.9 & 555 & Grout-bar bond failure \\
\hline 199 & $-1.5 d$ & 311 & 4.7 & 588 & Grout-bar bond failure \\
\hline 206 & $-1.0 d$ & 318 & 5.8 & 594 & Grout-bar bond failure \\
\hline $213\left(\mathrm{~L}_{\mathrm{cr}}\right)$ & $-0.5 d$ & 325 & 6.4 & 597 & Bar fracture \\
\hline 220 (tested) & 0 & 332 & 6.3 & 597 & Bar fracture \\
\hline
\end{tabular}

Table 6. Optimization design of the splices in terms of critical lengths

\begin{tabular}{|c|c|c|c|c|c|c|c|c|c|}
\hline \multirow[b]{2}{*}{$\begin{array}{c}\text { Specimen } \\
\text { No. }\end{array}$} & \multirow{2}{*}{$\begin{array}{c}\text { Sleeve length } \\
\text { in tests } \\
L[\mathrm{~mm}]\end{array}$} & \multirow[b]{2}{*}{$\Delta I[\mathrm{~mm}]$} & \multirow{2}{*}{$\begin{array}{c}\text { Critical } \\
\text { sleeve } \\
\text { length } L_{\mathrm{cr}} \\
\quad[\mathrm{mm}]\end{array}$} & \multicolumn{2}{|c|}{ Before optimization } & \multicolumn{2}{|c|}{ After optimization } & \multirow[b]{2}{*}{$\delta_{a o} / \delta_{\text {bo }}$} & \multirow[b]{2}{*}{$\sigma_{\text {u.ao }} / \sigma_{\text {u.bo }}$} \\
\hline & & & & $\begin{array}{c}\text { Relative } \\
\text { elongation } \delta_{\text {bo }}[\%]\end{array}$ & $\begin{array}{c}\sigma_{\text {u.bo }} \\
{[\mathrm{MPa}]}\end{array}$ & $\begin{array}{c}\text { Relative elongation } \\
\delta_{\mathrm{ao}}[\%]\end{array}$ & $\begin{array}{c}\sigma_{\text {u.ao }} \\
{[\mathrm{MPa}]}\end{array}$ & & \\
\hline H400D14 & 220 & $-0.5 d$ & 213.00 & 6.3 & 597 & 6.4 & 597 & 1.02 & 1.00 \\
\hline H400D16 & 220 & $0.5 d$ & 228.00 & 6.1 & 584 & 6.6 & 619 & 1.08 & 1.06 \\
\hline H400D20 & 290 & $-2.0 d$ & 250.00 & 6.2 & 522 & 7.0 & 522 & 1.13 & 1.00 \\
\hline H400D22 & 290 & $0.5 d$ & 301.00 & 3.7 & 587 & 7.1 & 628 & 1.92 & 1.07 \\
\hline H400D25 & 320 & $0.5 d$ & 332.50 & 4.4 & 567 & 6.6 & 595 & 1.49 & 1.05 \\
\hline H400D32 & 403 & $0.5 d$ & 419.00 & 4.8 & 531 & 6.6 & 531 & 1.39 & 1.00 \\
\hline H500D14 & 220 & $-1.5 d$ & 199.00 & 5.2 & 668 & 5.9 & 668 & 1.13 & 1.00 \\
\hline H500D16 & 220 & $0.5 d$ & 228.00 & 5.4 & 651 & 7.1 & 684 & 1.31 & 1.05 \\
\hline H500D20 & 290 & $0.5 d$ & 300.00 & 4.6 & 706 & 5.2 & 720 & 1.11 & 1.02 \\
\hline H500D22 & 290 & $0.5 d$ & 301.00 & 5.9 & 676 & 6.3 & 690 & 1.06 & 1.02 \\
\hline H500D25 & 320 & $0.5 d$ & 332.50 & 4.1 & 646 & 6.6 & 672 & 1.61 & 1.04 \\
\hline H500D32 & 403 & $0.5 d$ & 419.00 & 4.2 & 628 & 7.0 & 647 & 1.66 & 1.03 \\
\hline \multicolumn{4}{|c|}{$\begin{array}{c}\text { Mean value } \\
\text { (coefficient of variation) }\end{array}$} & - & - & - & - & $\begin{array}{c}1.33 \\
(0.22)\end{array}$ & $\begin{array}{c}1.03 \\
(0.02)\end{array}$ \\
\hline
\end{tabular}

used in product design to improve deformation properties of the splices with implementation of material savings and cost reduction.

\section{Conclusions}

Experimental study and numerical simulation were conducted to investigate the improvement of deformation properties and their influencing factors on sleeve length. The following conclusions could be drawn based on study results.

- Deformation properties of splices failed due to bar fracture showing a relatively large deformation resistance when compared to grout-bar bond failure. As a result, bar fracture is preferred to grout-bar bond failure. Essentially, sleeve length was one of the key factors that determined failure modes.

- A specific critical sleeve length existed for a specific splice which is a meaningful concept for understanding the deformation behaviour of splices. Splices with sleeves of critical lengths maximized the relative elongations of the splices.

\section{Acknowledgments}

Authors thank Kwang-Hua Education Foundation for financial support. 


\section{REFERENCES}

[1] Einea, A., Yamane, T., Tadros, M.K.: Grout-filled pipe splices for precast concrete construction, PCl Journal, 40 (1995) 1, pp. 8293, https://doi.org/10.15554/pcij.01011995.82.93

[2] Jansson, P.O.: Evaluation of grout-filled mechanical splices for precast concrete construction, Michigan Department of Transportation MDOT, 2008.

[3] Ling, J.H., Rahman, A.B.A., Ibrahim, I.S., et al.: Behaviour of grouted pipe splice under incremental tensile load, Construction and Building Materials, 33 (2012), pp. 90-98, https://doi. org/10.1016/j.conbuildmat.2012.02.001

[4] Ling, J.H., Rahman, A.B.A., Ibrahim, I.S.: Feasibility study of grouted splice connector under tensile load, Construction and Building Materials, 50 (2014), pp. 530-539, https://doi.org/10.1016/j. conbuildmat.2013.10.010

[5] Hosseini, S.J.A., Rahman, A.B.A.: Analysis of spiral reinforcement in grouted pipe splice connectors, Građevinar, 65 (2013) 6, pp. 537-546.

[6] Henin, E., Morcous, G.: Non-proprietary bar splice sleeve for precast concrete construction, Engineering Structures, 83 (2015), pp. 154-162.
[7] American Concrete Institute: Building code requirements for structural concrete and commentary (ACl-318), Farmington Hills, MI, USA, 2008, https://doi.org/10.1016/j.engstruct.2014.10.045

[8] ICC Evaluation Service, Inc.: Acceptance criteria for mechanical connector systems for steel reinforcing bars (AC-133). Birmingham, AL, USA, 2008.

[9] British Standards BSI: Structural use of concrete - Part 1: code of practice for design and construction (BS8110-1:1997), British Standards Institution, London, UK, 1997.

[10] Ministry of Housing and Urban-Rural Development of the People's Republic of China: Technical specification for grout sleeve splicing of rebars (JGJ355-2015). China Architecture \& Building Press, Beijing, PR China, 2015. (in Chinese)

[11] Ameli, M.J., Parks, J.E., Brown, D.N., Pantelides, C.P.: Seismic evaluation of grouted splice sleeve connections for reinforced precast concrete column-to-cap beam joints in accelerated bridge construction. PCI Journal, 60 (2015) 2, pp. 80-103, https://doi. org/10.15554/pcij.03012015.80.103

[12] Steuck, K.P., Eberhard, M.O., Stanton, J.F.: Anchorage of largediameter reinforcing bars in ducts. ACI Structural Journal, 106 (2009) 4, pp. 506-513. 